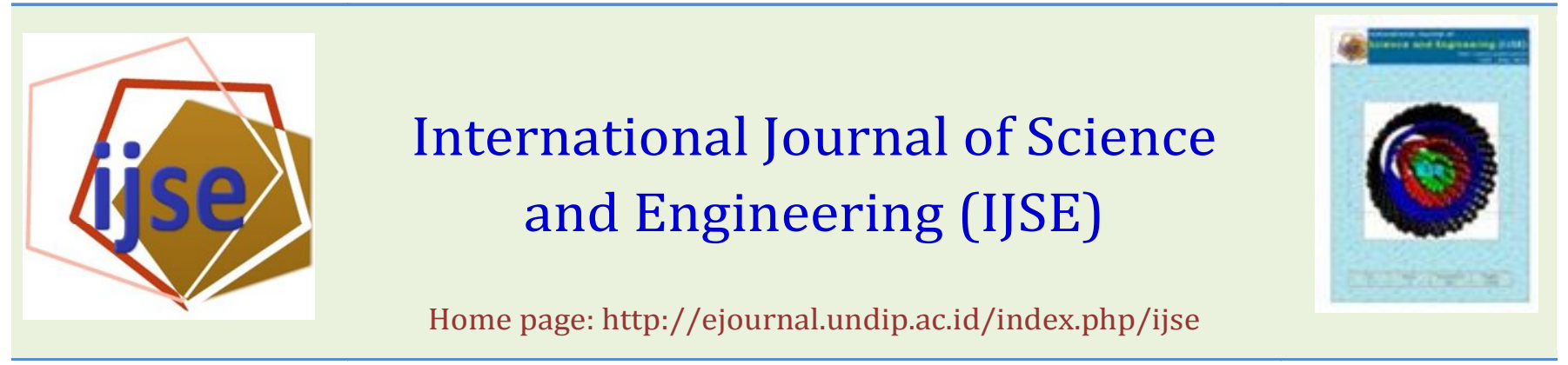

\title{
Experimental Design of Electrocoagulation and Magnetic Technology for Enhancing Suspended Solids Removal from Synthetic Wastewater
}

\author{
Moh Faiqun Ni'am ${ }^{1 *}$ and Fadil Othman ${ }^{2}$ \\ 1 Dept. of Environmental Eng., Fac. of Engineering, Universitas Islam Sultan Agung, Semarang 50112, Indonesia. \\ 2 Dept. of Environmental Eng., Fac. Of Civil Eng., Universiti Teknologi Malaysia, Johor 81310, Malaysia. \\ *Corresponding author: irfani_mt@yahoo.com ; Tel.: +62246583584 ; fax: +62246582455.
}

\begin{abstract}
Design of experiments (DOE) is one of the statistical method that is used as a tool to enhance and improve experimental quality. The changes to the variables of a process or system is supposed to give the optimal result (response) and quite satisfactory. Experimental design can defined as a test or series of test series by varying the input variables (factors) of a process that can known to cause changes in output (response). This paper presents the results of experimental design of wastewater treatment by electrocoagulation (EC) technique. The objectives of this study were to investigate the suitability of magnetic fields and electrocoagulation technologies for the treatment of wastewater in enhancing removal of suspended solids and its sedimentation. A combined magnet and electrocoagulation (EC) technology were designed to increase settling velocity and to enhance suspended solid removal efficiencies from wastewater samples. In this experiment, a synthetic wastewater samples were prepared by mixing $700 \mathrm{mg}$ of the milk powder in one litre of water and treated by using an acidic buffer solution. The monopolar iron (Fe) plate anodes and cathodes were employed as electrodes. Direct current was varied in a range of between 0.5 and $1.1 \mathrm{~A}$, and flowrate in a range of between 1.00 to $3.50 \mathrm{~mL} / \mathrm{s}$. One permanent magnets namely AlNiCo with a magnetic strength of 0.16T was used in this experiment. The results show that the magnetic field and the flowrate have major influences on suspended solids removal. The efficiency removals of suspended solids, turbidity and COD removal efficiencies at optimum conditions were found to be more than $85 \%$, 95\%, and $75 \%$, respectively.
\end{abstract}

Keywords - Electrocoagulation; Magnetic field; Wastewater treatment; Experimental design; Response surface methodology Submission: March 26, $2014 \quad$ Correction: June 4, 2014 Accepted: August 8, 2014 Doi: 10.12777 ijse.7.2.178-192

[How to cite this article: Ni'am, M.F. and Othman, F. (2014 Experimental Design of Electrocoagulation and Magnetic Technology for Enhancing Suspended Solids Removal from Synthetic Wastewater. International Journal of Science and Engineering, 7(2),178-192. Doi: 10.12777/ijse.7.2.178-192]

\section{INTRODUCTION}

Colloidal or fine particles, commonly called suspended solids, are extremely small and light, which will not settle out by gravity. Colloidal particle size is approximately 0.001 microns to 1 microns ( $1 \mathrm{~nm}$ to $1 \mathrm{~m}$ ) in dimension. One of the most common example of colloids is milk (Shaw, 1970; Hiemenz and Rajagopalan, 1997). Because of difficult to settle under gravity, hence coagulation are needed so that the particle size becomes relatively larger. An alternative separation treatment for ultrafine particles is electrocoagulation (EC), which involves the in situ formation of ions by electrolysis. The key foundation sciences for electrocoagulation are electrochemistry, coagulation, and flotation.

Electrocoagulation technology, has reached profitable commercialization, and existing ones improved that do not require chemical additions (Mollah et al., 2001).
These include electrocoagulation (EC), electroflotation (EF), electrodeposition (ED), electrooxidation (EO), and others (Chen, 2004). The main based of electrocoagulation technology is electrochemistry, coagulation, and flotation, and the relevant mechanism of their interaction, which are extracted and applied in the electrocoagulation context.

EC has been used by various authors for the treatment of wastewater for different wastes, e.g. soluble oils, liquid from the food, textile industries, or cellulose and effluents from the paper industry, landfill leachate, restaurant wastewater, saline wastewater, tar sand and oil shale wastewater, urban wastewater, laundry wastewater, nitrate and arsenic bearing wastewater, and chemical mechanical polishing wastewater (Holt et al., 2002; Calvo et al., 2003; Kobya et al., 2003; Larue et al., 2003; Daneshvar et al., 2004; Kumar et al., 2004; Can et al., 
2006; Carmona et al., 2006; Ilhan et al., 2008). Several differences were found in comparison to the chemical coagulation process (Zhu et al., 2005; Meunier et al., 2006) and economical evaluation (Kobya et al., 2007 and 2009).

Aluminium or iron are usually used as electrodes and their cations are generated by dissolution of sacrificial anodes upon the application of a direct current (Carmona et al., 2006; Ilhan et al., 2008; Hernandez et al., 2009; Zongo et al., 2009; Tchamango et al., 2010). The results obtained that the aluminium and iron are suitable electrode materials for the treatment of textile wastewaters by electrocoagulation.

Whereas, magnetic treatments for water and wastewater attract a special attention due to their safety, ecological purity, environmental friendly and simplicity. Magnetic treatment of water was first patented by Vermeiren in Belgium in 1945, and he is recognized as the discoverer of the fact that magnetic fields affect water. Magnetic treatment of water is an attractively simple approach by which the water to be treated flows through a magnetic field, and consequently changes some of its physicochemical properties (Othman et al., 2001; Sohaili et al., 2004; Ni'am et al., 2006).

Magnetic field is known to create the asymmetry of hydrated shells due to its effect on water molecules situated around the charged particles (colloid). Exposure to magnetic field would lead to higher electro-kinetic movement among the colloid. This definitely will help in attributing to a higher probability of attracting particles to cloak with one another. The theory of magnetic field impact on technological processes for water treatment falls into two main categories; crystallization at magnetic water preparation and impurity coagulation in water systems (Othman et al., 2001).

In fact, from the literature study of previous research, very little available literature on water and wastewater treatment using a combination of EC and magnetic fields. Electrocoagulation (EC) has investigated by Tsouris et al. (2001), as a magnetic seeding method to be used prior to a high-gradient magnetic separation (HGMS) process. Ihara et al. (2004) have treated landfill leachate in a bench scale plant by high gradient magnetic separation combined with electrocoagulation using iron electrodes and electrochemical oxidation. Meanwhile, Ghernaout et al. (2009), have studied the reduction of humic acids (HA) by continuous electromagnetic (EM) treatment followed by electrocoagulation (EC) in batch of synthetic HA solution using two aluminium electrodes at neutral $\mathrm{pH}$.

In the preliminary research, the authors have investigated the effect of EC with iron (Fe) bar and plate electrodes in the batch experiment (Ni'am et al., 2005, 2007a,b and 2008; Othman et al., 2006). The results of a combined magnetic field and EC with Fe bar electrodes shown that the SS and turbidity removal are as high as $91.4 \%$ and $85.5 \%$ with the combined process, while for EC process is as high as $88 \%$ and $72.1 \%$ (Ni'am et al., 2005).

In another research, Othman et al. (2005) have investigated that the SS and turbidity removal are as high as $92.3 \%$ and $81.25 \%$ with the combined process, while for EC process is as high as $89.3 \%$ and $75.16 \%$. These results obtained from batch experiment by a combined magnetic field and EC with iron (Fe) plate electrodes.

The objectives of this study were to investigate the suitability of magnetic fields and electrocoagulation technologies for the treatment of wastewater in enhancing removal of suspended solids and its sedimentation.

\section{MATERIALS AND METHODS}

This research is mainly focused on the capability of magnetic field and EC technology to removal and increase the sedimentation of suspended solid through single flow processing methods. Response surface methodology (RSM) is employed to optimize and to analyze interactions of influencing factors on the treatment efficiency of synthetic wastewater with some planned experiments.

\section{A. Synthetic Wastewater}

The synthetic wastewater were prepared from milk powder with concentrations of $700 \mathrm{mg} / \mathrm{L}$ and treated by using a buffer solution. The buffer solution consisted of 5 $\mathrm{mL} / \mathrm{L} \mathrm{HCl}(0.5 \%)$ and $125 \mathrm{mg} / \mathrm{L} \mathrm{NaCl}$ as $\mathrm{pH}$ adjusment and electrolyte. From these concentrations (after adjusted by buffer solution), the initial $\mathrm{pH}$ of the wastewater was found to be 2.91 and maximum current was $1.4 \mathrm{~A}$ at a voltage of $30 \mathrm{~V}$. The current was adjusted to a desired value between $0.50 \mathrm{~A}$ and $1.1 \mathrm{~A}$ before the coagulation process started.

\section{B. Experimental Setup}

The experiments were carried out in this work as a single flow method. EC and the synthetic wastewater were performed in the reactor glass cell (volume 2000 $\mathrm{mL}$ ). Fifteen monopolar plate electrodes (100 x 50 × 4 $\mathrm{mm}$ ) from iron ( $\mathrm{Fe}$ ) plates were set up as a baffle at distances of $14 \mathrm{~mm}$ and placed in the reactor.

The wastewater flows from reservoir (volume 8000 $\mathrm{mL}$ ) throughout the system is provided by means of a pump controlled and can be adjusted from zero to maximum $15 \mathrm{~mL} / \mathrm{s}$. In this research, the wastewater was circulated with a constant flowrate, varied between 1.00 $\mathrm{mL} / \mathrm{s}$ and $3.50 \mathrm{~mL} / \mathrm{s}$. The experimental setup was shown in Figure 1.

One permanent magnets namely AlNiCo with a magnetic strength of $0.16 \mathrm{~T}$ was used. Three pairs of magnets have been placed under the reactor. Each pair consists of two-piece magnets of cubic-shaped rare earth permanent magnets (size $50 \mathrm{~mm}$ x $50 \mathrm{~mm}$ x $20 \mathrm{~mm}$ ). Furthermore, the treated wastewater was placed in graduated sedimentation columns of $5 \mathrm{~cm}$ internal diameter and $1 \mathrm{~m}$ height for 6 to 24 hours settling time. Samples were collected at $5 \mathrm{~cm}$ from the surface of wastewater using pipette, at 30, 60, 90 minutes and 2, 3, 4, $6,8,12$ hours of settling time. The effects of relevant wastewater characteristic such as turbidity, COD, and SS removal efficiencies have been explored. 

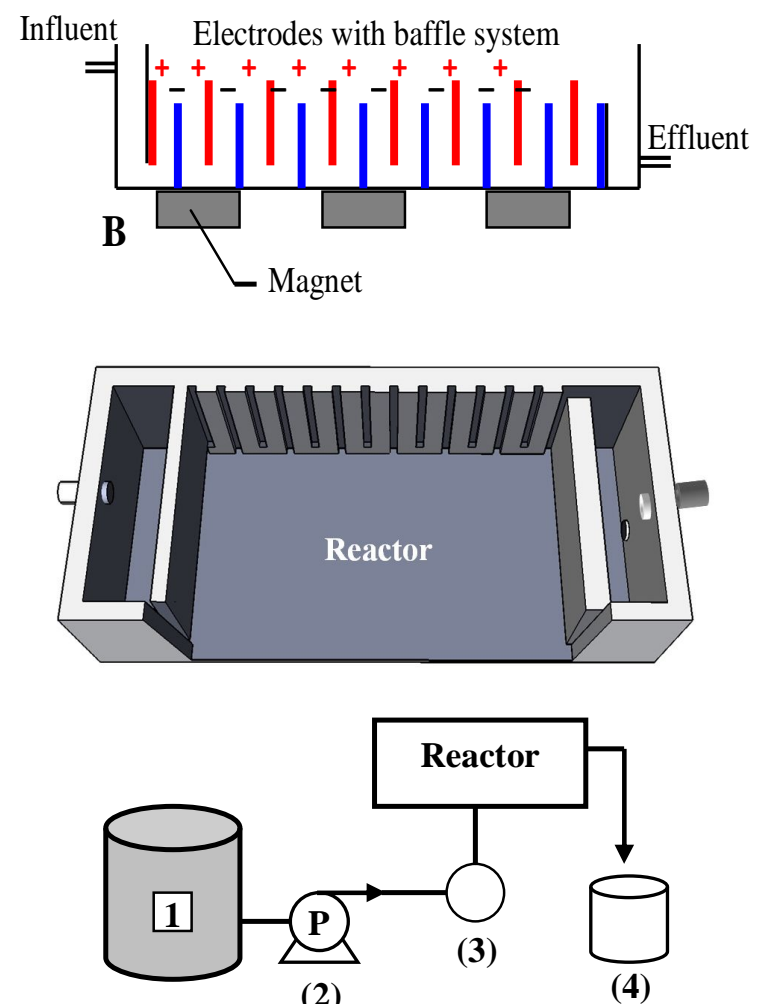

Fig. 1. Detail of EC reactor and Experimental setup: (1) reservoir with mixing, (2) circulation pump, (3) flowrate meter, reactor, and (4) effluent \& sample collecting

\section{Experimental Design and Analytical Method}

Optimization of suspended solids removal from wastewater was carried out using RSM. According to Montgomery (2001), RSM is a collection of mathematical methods and statistical techniques that aims to create models and perform analysis of the responses that are influenced by several variables and the objective is to optimize this response.

For statistical analysis, analysis of variance, better known by the name of ANOVA from MINITAB ${ }^{\mathrm{TM}}$ (Version 14.0) was used. Analysis of Variance (ANOVA) is a method of analysis used to investigate the relationship between the response variable (dependent) with one or more predictor (independent). ANOVA is similar to regression, but the data's scale of independent variable is data of categories, i.e.: ordinal or nominal scale. ANOVA also did not have the coefficient (parameter) of the model.

The turbidity removal was measured from wastewater samples by HACH DR/4000 (HACH Method 10047). COD measurements were determined according to the Standard Methods for Examination of Water and Wastewater (APHA, 2005). The COD samples were analyzed using UV-Vis HACH DR/4000 spectrophotometer (HACH Method 8000).

To measure total suspended solid (TSS), the wastewater samples were filtered through a standard $\mathrm{GF} / \mathrm{F}$ glass fiber filter. The residue retained on the filter was dried in an oven at $103^{\circ} \mathrm{C}$ to $105^{\circ} \mathrm{C}$ until the weight of the filter no changes. The increase in weight of the filter represents the total suspended solids (APHA Method 2540 D).
The calculation of turbidity, COD and suspended solid removal efficiencies after electrocoagulation treatment were performed using this formula (Daneshvar et al., 2006):

$$
C R(\%)=\frac{C_{0}-C}{C_{0}} \times 100
$$

Where $\mathrm{C}_{0}$ and $\mathrm{C}$ are concentrations of wastewater before and after electrocoagulation in NTU or mg/L, respectively.

According to Matteson et al. (1995), the rate of change of wastewater concentration, such as turbidity, COD and suspended solid removal can be expressed as a first order kinetic model, as follows:

$$
\frac{C}{C_{o}}=e^{-k_{2} t}
$$

Where $\mathrm{C}, \mathrm{Co}$, and $k_{2}$ are wastewater concentrations after EC, initial, and kinetic constant, respectively.

Hence, the loss of particles due to coagulation after treatment process (Sohaili, 2003), as follows:

$$
\frac{C}{C_{o}}=a\left(b-e^{-k t}\right)
$$

Where $\mathrm{k}$ is kinetic constant; $\mathrm{a}$ and $\mathrm{b}$ are constant values.

\section{RESULT AND DISCUSSION}

\section{A. Experimental Design}

For obtain the optimum values, this study was carried out in the preliminary tests by experimental design using Response Surface Methodology (RSM) in the batch experiment. Montgomery (2001) and Antony (2003) explained that the experimental design is an important 
role in the development process and can be used to solve the problems in the process for improved of process performance. Meanwhile in the second stage, the main experiment was performed with a single flow system using the optimum values have been obtained from simulation of the preliminary tests. To create the experimental design and analyze statistical data, the MINITAB $^{\text {TM }}$ (Version 14.0) statistical application program was used.

Table 1: Values of variables will be tested in the batch experiment to obtain optimum value.

\begin{tabular}{lcccc}
\multicolumn{1}{c}{ Variables/Factors } & Levels & \multicolumn{3}{c}{ Values } \\
\hline Distance of electrodes (d) & 3 & $14 \mathrm{~mm}$ & $32 \mathrm{~mm}$ & $50 \mathrm{~mm}$ \\
\hline Current (i) & 3 & $0.5 \mathrm{~A}$ & $0.8 \mathrm{~A}$ & $1.1 \mathrm{~A}$ \\
\hline Treatment Time $\left(\mathrm{t}_{1}\right)$ & 3 & $20^{\prime}$ & $30^{\prime}$ & $40^{\prime}$ \\
\hline
\end{tabular}

Three variables and three levels Central Composite Design (CCD) consisting of twenty experimental runs order were employed. The design variables were distance between electrodes (d), direct current (i), and treatment time $\left(t_{1}\right)$ while three important response variables were
Suspended Solids (SS), turbidity, and COD removal efficiencies. Values of each variable that will be tested in this experiment conducted in one replicate, as indicated in Table 1.

Table 2: Values of actual level for RSM design by using MINITAB.

\begin{tabular}{cccccc}
\hline \multirow{2}{*}{ Factors } & \multicolumn{5}{c}{ Values } \\
\cline { 2 - 6 } & -1.68 & -1.00 & 0.00 & 1.00 & 1.68 \\
\hline $\mathrm{X}_{1}=$ distance $(\mathrm{mm})$ & 1.72 & 14 & 32 & 50 & 62.28 \\
\hline $\mathrm{X}_{2}=$ current $(\mathrm{A})$ & 0.3 & 0.5 & 0.8 & 1.1 & 1.3 \\
\hline $\mathrm{X}_{3}=$ time (minute) & 13.18 & 20 & 30 & 40 & 46.82 \\
\hline
\end{tabular}

Table 3: Experimental design and results information by RSM using CCD type.

\begin{tabular}{|c|c|c|c|c|c|c|c|c|c|}
\hline $\begin{array}{c}\text { Std } \\
\text { Order }\end{array}$ & $\begin{array}{l}\text { Run } \\
\text { Order }\end{array}$ & Pt Type & Blocks & $\begin{array}{c}\text { Treatment } \\
\text { (t) } \\
(\mathrm{min})\end{array}$ & $\begin{array}{c}\text { Distance } \\
\text { (d) } \\
(\mathrm{mm})\end{array}$ & $\begin{array}{c}\text { Current } \\
\text { (i) } \\
\text { (A) }\end{array}$ & $\begin{array}{c}\text { \% SS } \\
\text { Removal }\end{array}$ & $\begin{array}{c}\text { \% Turbidity } \\
\text { Removal }\end{array}$ & $\begin{array}{c}\text { \% COD } \\
\text { Removal }\end{array}$ \\
\hline 1 & 1 & 1 & 1 & 20 & 14 & 0.5 & 66.643 & 81.874 & 49.035 \\
\hline 2 & 2 & 1 & 1 & 40 & 14 & 0.5 & 85.643 & 89.817 & 75.702 \\
\hline 3 & 3 & 1 & 1 & 20 & 50 & 0.5 & 54.071 & 50.509 & 43.596 \\
\hline 4 & 4 & 1 & 1 & 40 & 50 & 0.5 & 72.357 & 78.615 & 66.053 \\
\hline 5 & 5 & 1 & 1 & 20 & 14 & 1.1 & 78.786 & 90.428 & 77.193 \\
\hline 6 & 6 & 1 & 1 & 40 & 14 & 1.1 & 74.714 & 88.595 & 55.439 \\
\hline 7 & 7 & 1 & 1 & 20 & 50 & 1.1 & 74.000 & 66.599 & 68.070 \\
\hline 8 & 8 & 1 & 1 & 40 & 50 & 1.1 & 83.214 & 97.963 & 79.386 \\
\hline 9 & 9 & -1 & 1 & 13.18 & 32 & 0.8 & 66.000 & 34.000 & 46.500 \\
\hline 10 & 10 & -1 & 1 & 46.82 & 32 & 0.8 & 80.000 & 96.000 & 76.000 \\
\hline 11 & 11 & -1 & 1 & 30 & 1.72 & 0.8 & 80.643 & 88.595 & 76.228 \\
\hline 12 & 12 & -1 & 1 & 30 & 62.28 & 0.8 & 74.143 & 72.301 & 68.246 \\
\hline 13 & 13 & -1 & 1 & 30 & 32 & 0.3 & 44.071 & 74.134 & 31.316 \\
\hline 14 & 14 & -1 & 1 & 30 & 32 & 1.3 & 85.500 & 97.352 & 82.193 \\
\hline 15 & 15 & 0 & 1 & 30 & 32 & 0.8 & 84.214 & 96.130 & 69.386 \\
\hline 16 & 16 & 0 & 1 & 30 & 32 & 0.8 & 84.214 & 96.130 & 69.386 \\
\hline 17 & 17 & 0 & 1 & 30 & 32 & 0.8 & 84.214 & 96.130 & 69.386 \\
\hline 18 & 18 & 0 & 1 & 30 & 32 & 0.8 & 84.214 & 96.130 & 69.386 \\
\hline 19 & 19 & 0 & 1 & 30 & 32 & 0.8 & 84.214 & 96.130 & 69.386 \\
\hline 20 & 20 & 0 & 1 & 30 & 32 & 0.8 & 84.214 & 96.130 & 69.386 \\
\hline
\end{tabular}


By using RSM, the experimental work in this study was designed statistically using Selections of the values for each independent variable were decided upon based on the variable range input to the MINITAB Statistical Software. By selecting the design type of CCD, values of actual levels of each factor in Table 1 are recalculated using the following equation:

$$
\begin{aligned}
& \mathrm{X}_{1}=\frac{\text { distance }-32}{18} \\
& \mathrm{X}_{2}=\frac{\text { current }-0.8}{0.3}
\end{aligned}
$$

$$
\mathrm{X}_{3}=\frac{\text { treaatment time }-30}{10}
$$

The calculation result of the actual level values using the formulas above, as shown in Table 2 and then performed of design analysis by using MINITAB software.

The experiment was done with the values of the design information that has (4gen combined by MINITAB (Table 3). The experimental results of SS, turbidity and COD removal as shown in Table 3 , then used as input data in MINITAB program to be 5 modeled and analyzed the design and statistics. Output of response surface regression of SS removal efficiency as shown as follows:
Term
Constant
Treatment (t1)
Distance (d)
Current (i)
Coef SE Coef $\quad \mathrm{T} \quad \mathrm{P}$
$84.127 \quad 2.815 \quad 29.881 \quad 0.000$
$\begin{array}{lllll}4.831 & 1.868 & 2.586 & \underline{0.027}\end{array}$
$\begin{array}{lllll}-2.422 & 1.868 & -1.297 & 0.224\end{array}$
$\begin{array}{llll}7.445 & 1.868 & 3.986 \underline{0.003}\end{array}$
Treatment (t1)*Treatment (t1)
Distance (d)*Distance (d) $\quad-1.840 \quad 1.818-1.012 \quad 0.335$
Current (i)*Current (i) $\quad \begin{array}{lllll}-6.297 & 1.818 & -3.463 & \underline{0.006}\end{array}$
Treatment (t1)*Distance (d) $\quad 1.572 \quad 2.441 \quad 0.644 \quad 0.534$
Treatment (t1)*Current (i) $\quad-4.018 \quad 2.441 \quad-1.646 \quad 0.131$
Distance (d)*Current (i) $\quad 3.697 \quad 2.441 \quad 1.515 \quad 0.161$

\begin{tabular}{|c|c|c|c|c|c|c|}
\hline Source & DF & Seq SS & Adj SS & Adj MS & $\mathrm{F}$ & $\mathrm{P}$ \\
\hline Regression & 9 & 2110.6 & 2110.6 & 234.52 & 4.92 & 0.010 \\
\hline Linear & 3 & 1155.8 & 1155.8 & 385.26 & 8.08 & $\underline{0.005}$ \\
\hline Square & 3 & 696.6 & 696.6 & 232.21 & 4.87 & $\underline{0.024}$ \\
\hline Interaction & 3 & 258.2 & 258.2 & 86.07 & 1.81 & $\underline{0.210}$ \\
\hline Residual Error & 10 & 476.5 & 476.5 & 47.65 & & \\
\hline Lack-of-Fit & 5 & 283.8 & 283.85 & 6.76 & 1.47 & $\underline{0.341}$ \\
\hline Pure Error & 5 & 192.7 & 192.7 & 38.55 & & \\
\hline
\end{tabular}

$\mathrm{S}=6.903 \quad \mathrm{R}-\mathrm{Sq}=81.6 \% \mathrm{R}-\mathrm{Sq}(\mathrm{adj})=65.0 \%$

Analysis of Variance for \% SS Removal

Estimated Regression Coefficients for \% SS Removal using data in uncoded units

$\begin{array}{ll}\text { Term } & \text { Coef } \\ \text { Constant } & 84.1268 \\ \text { Treatment (t1) } & 4.83077 \\ \text { Distance (d) } & -2.42191 \\ \text { Current (i) } & 7.44498 \\ \text { Treatment (t1)*Treatment (t1) } & -3.39301 \\ \text { Distance (d)*Distance (d) } & -1.83985 \\ \text { Current (i)*Current (i) } & -6.29727 \\ \text { Treatment (t1)*Distance (d) } & 1.57150 \\ \text { Treatment (t1)*Current (i) } & -4.01800 \\ \text { Distance (d)*Current (i) } & 3.69650\end{array}$



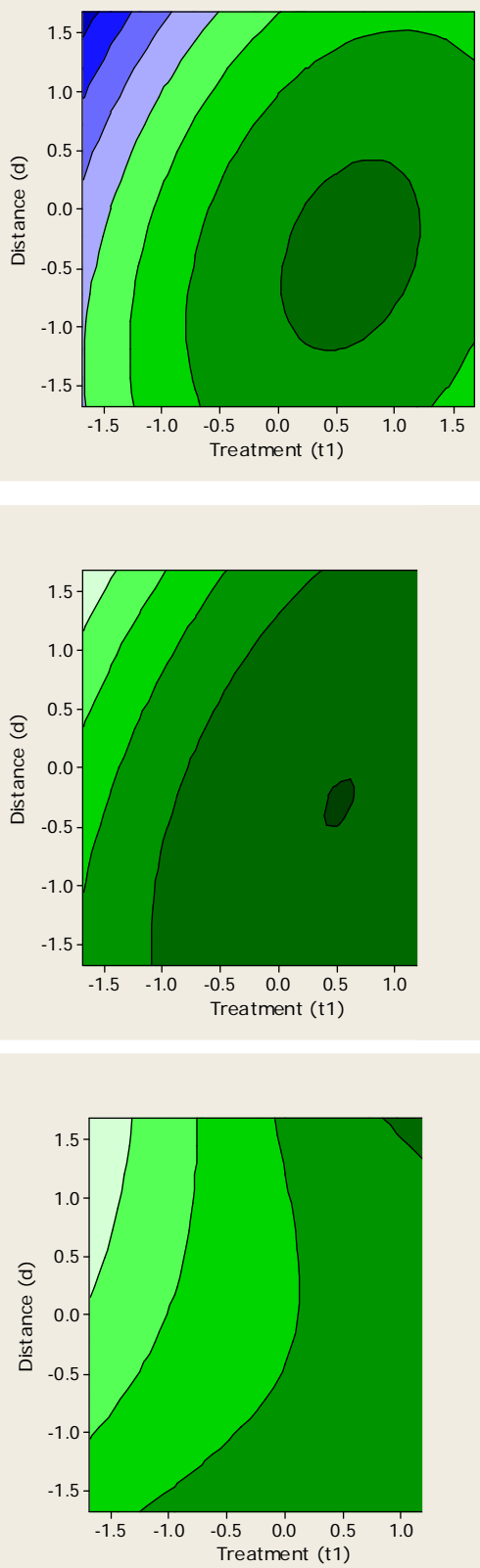

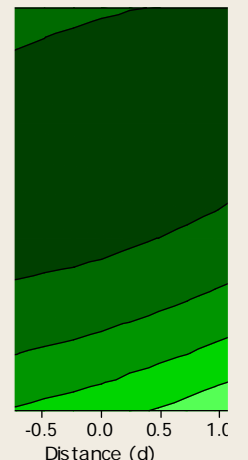

(a)
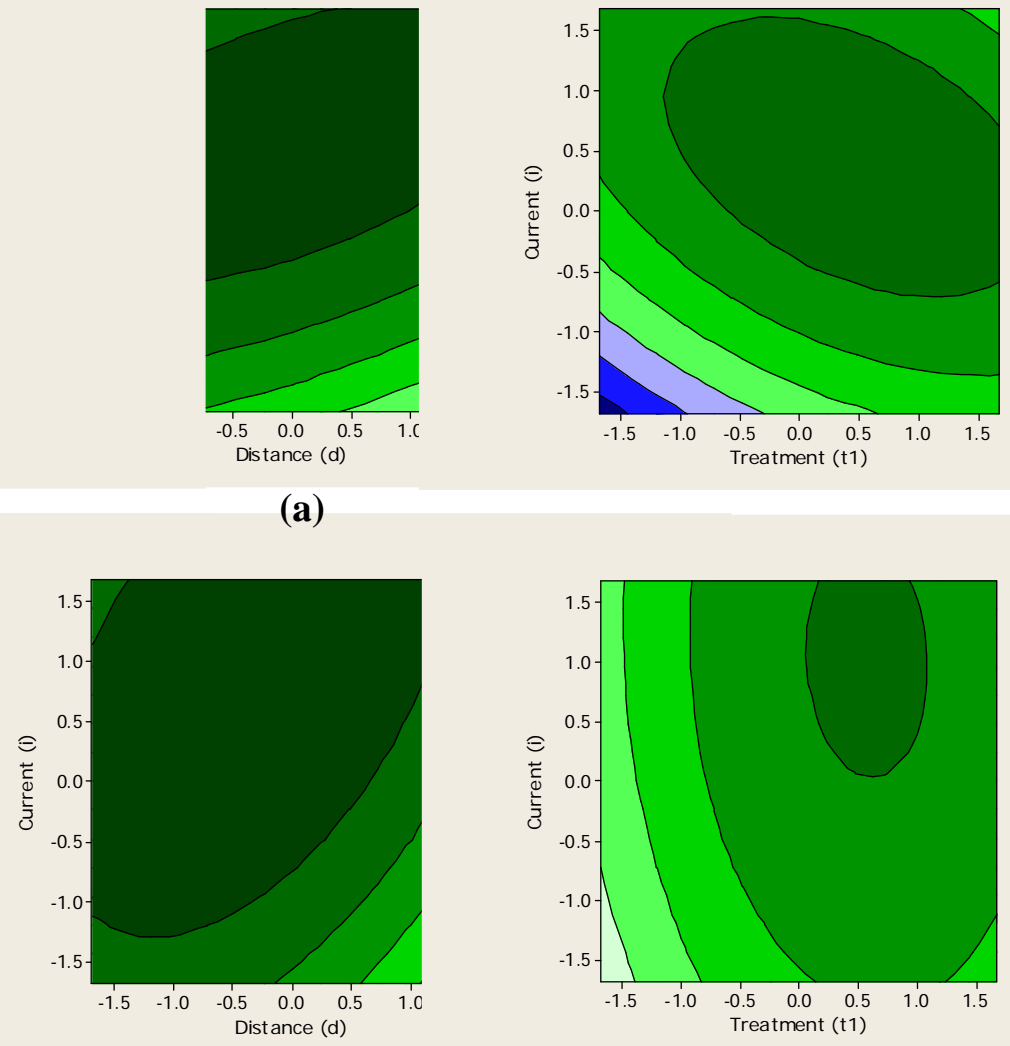

(b)
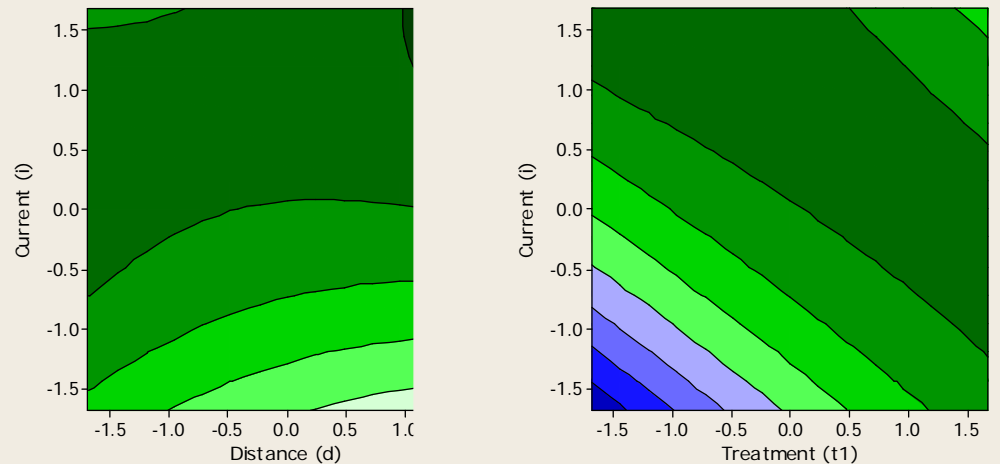

(c)

Fig. 2. Contour plot for combine effect of treatment time-distance, distance-current, and treatment time-current on percentage of (a) SS, (b) turbidity, and (c) COD removal.

The output above shows of several sections, including: the results of the estimated parameters of the model, ANOVA table used to test the suitability of the model with the data, and unusual observation. To perform the analysis of output, the first step is to detect the significances of the model. The significance of the model can be observed in the ANOVA table, which shows that the linear model ( $\mathrm{p}$-value $=0.005)$ and quadratic model ( $p$-value $=0.024)$ is significant because the $p$-value of both less than $\alpha=0.1$. Conversely, nonlinear model that includes interactions between factors ( $p$-value $=0.210$ ) were not significant. This means, the right model is a quadratic model. On the other hand, the parameters test of model also shows that the variable "treatment time", "current", "quadrate of treatment" and "quadrate of current" have significances because those terms have a small p-value or less than $10 \%$. 

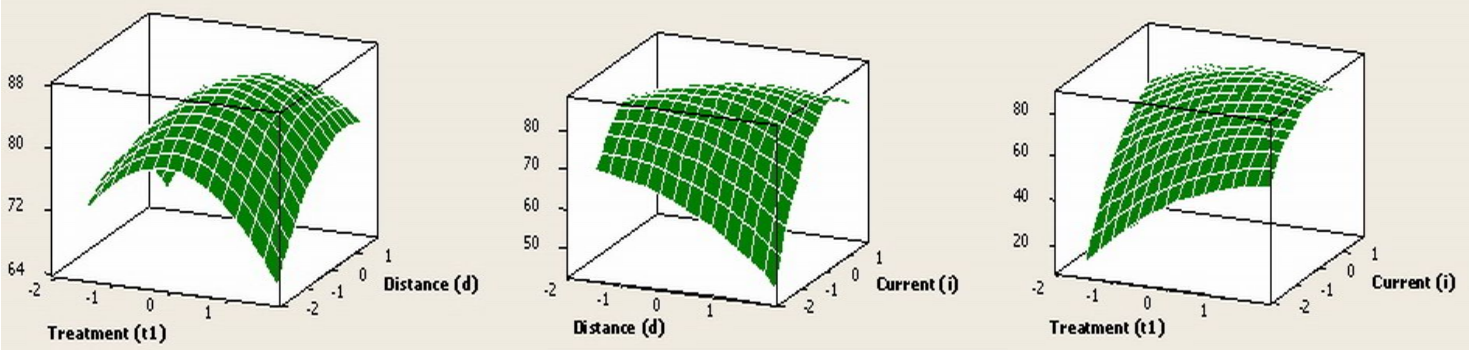

(a)
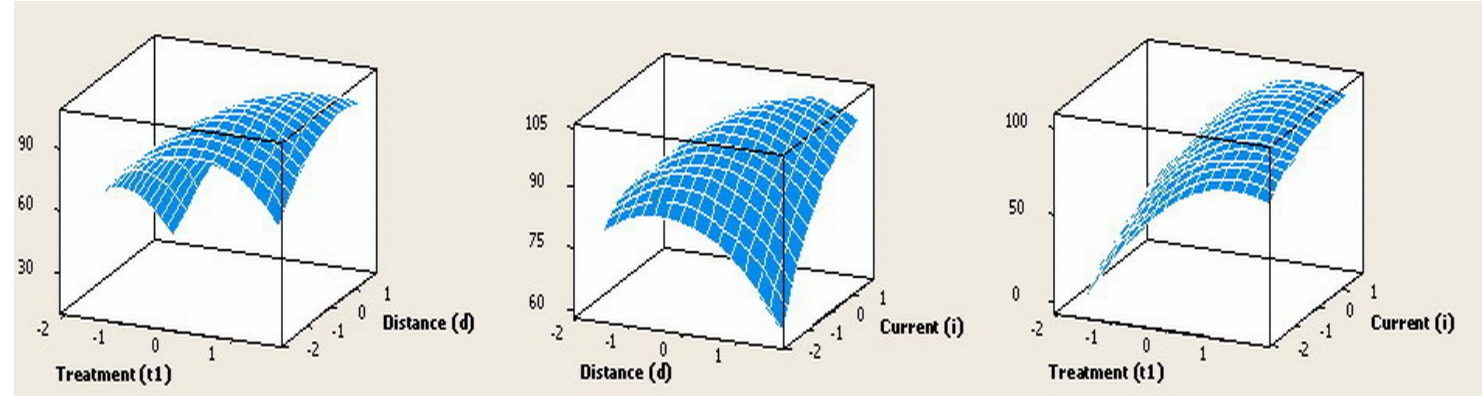

(b)
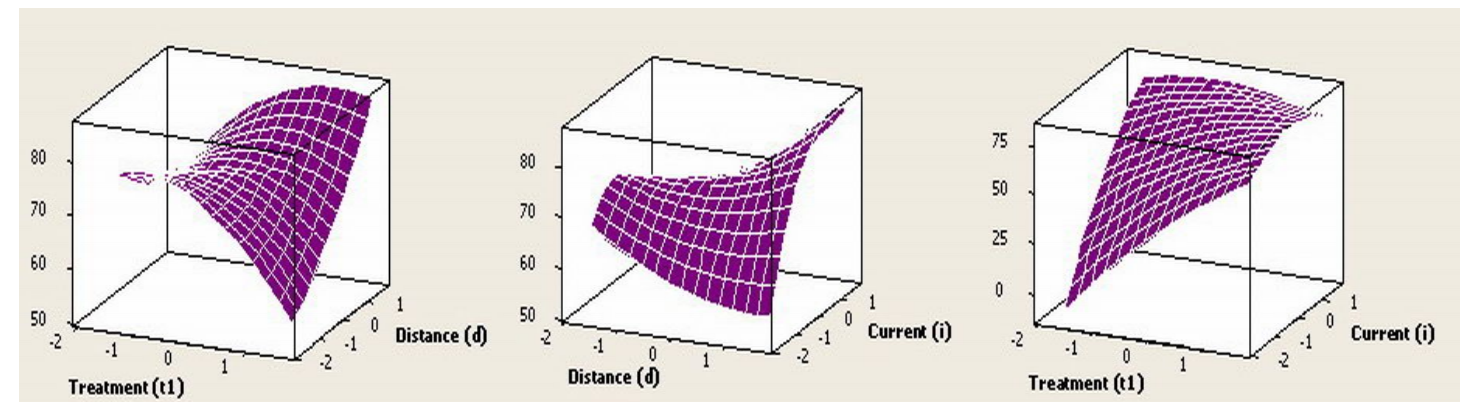

(c)

Fig. 3. 3D graphs of response surface plot for combine effect of treatment time-distance, distance-current, and treatment timecurrent on percentage of (a) SS, (b) turbidity, and (c) COD removal.

For the optimization model, the data are analyzed by making a contour plot of the response variable. To visualize the response in three-dimensional images, it would require two independent variables and one variable is set its value at normal conditions. In this analysis, the value of a specified variables are the variable "current", "treatment time", and "distance" with the value at normal conditions are $0.8 \mathrm{~A}, 30$ minutes, and $32 \mathrm{~mm}$, respectively.
Based on the output shown in Figure 2 and Figure 3. it can be concluded that the efficiency will be optimum when the treatment time is at a level between 0.0 to 1.0 (between 30 to 40 minutes) and distance between electrodes at a level between -1.0 to 0.0 (14 mm to 32 $\mathrm{mm})$.

Based on statistical analysis of the estimated regression coefficient using data in uncoded units for the experimental condition of this study, obtained following equation:

$$
y=84.13+\left(4.83^{*} t_{1}\right)-\left(2.42^{*} d\right)+\left(7.45^{*} i\right)-\left(3.4^{*} t^{2}\right)-\left(1.84^{*} d^{2}\right)-\left(6.3^{*} i^{2}\right)+\left(1.57^{*} t^{*} d\right)-\left(4.02^{*} t^{*} i\right)+\left(3.7^{*} d^{*} i\right)
$$

Where: $y=$ percentage of SS removal.

$\mathrm{t}_{1}=$ treatment time.

$\mathrm{d}=$ distance between electrodes.

$\mathrm{i}=$ direct current from power supply

Furthermore, based on one way method of statistical analysis of ANOVA on SS removal efficiency for interaction between three variables (Figure 4), obtained

results that the optimum value will be reached at distance $=14 \mathrm{~mm}$ and current $=0.8 \mathrm{~A}$ at treatment time $=$ 30 minutes. 


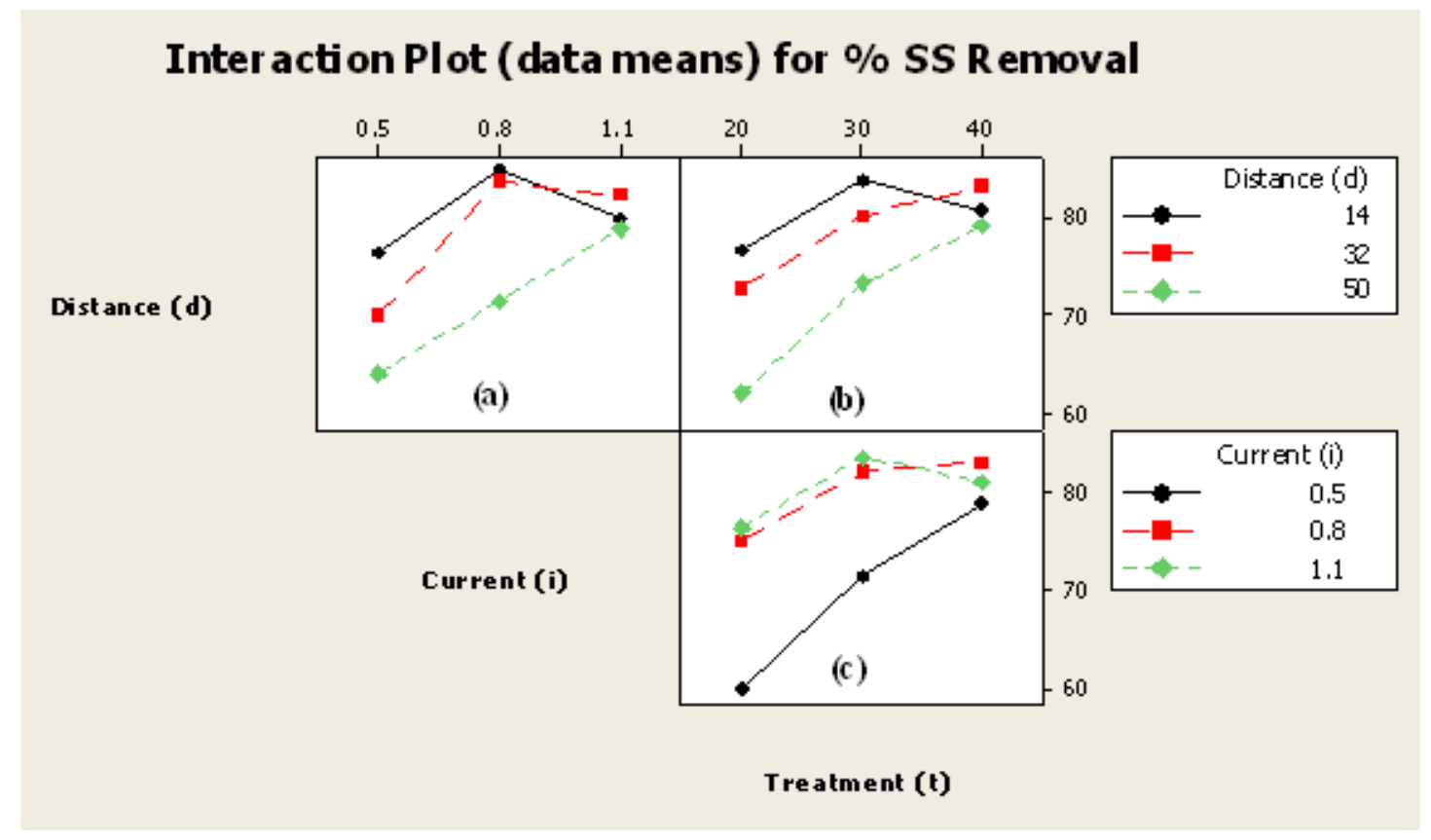

Fig. 4. Output of one way statistical analysis of ANOVA to predict of optimum value for three variables.

\section{B. Effect of Flowrate and Magnetic Fields}

Studies of influence of flowrate have been done by using single flow experiment. Wastewater were circulated through the reactor with three variations of flowrate are $1.1 \mathrm{~mL} / \mathrm{s}, 1.7 \mathrm{~mL} / \mathrm{s}$ and $3.3 \mathrm{~mL} / \mathrm{s}$. Determination of optimum flowrate is based on the reactor volume (2000 $\mathrm{mL})$ and optimum treatment time (30 minutes). To determine the optimum flowrate in the reactor, calculated using the following equation:

$$
Q=\frac{\text { Volume }}{\text { time }}=\frac{2000 \mathrm{~mL}}{30 \times 60 \mathrm{~s}}=1.111 \mathrm{~mL} / \mathrm{s}
$$

By the same method, obtained values of other

\begin{tabular}{||l|c|c|c|c||}
\hline \hline Variables/Factors & Levels & \multicolumn{3}{|c||}{ Values } \\
\hline Magnetic fields (B) & 2 & \multicolumn{2}{|c|}{ Without Magnet } & $0.16 \mathrm{~T}$ \\
\hline Flowrates (Q) & 3 & $1.1 \mathrm{~mL} / \mathrm{s}$ & $1.7 \mathrm{~mL} / \mathrm{s}$ & $3.3 \mathrm{~mL} / \mathrm{s}$ \\
\hline Cell current (i) & 1 & \multicolumn{3}{|c|}{$0.80 \mathrm{~A}$} \\
\hline
\end{tabular}

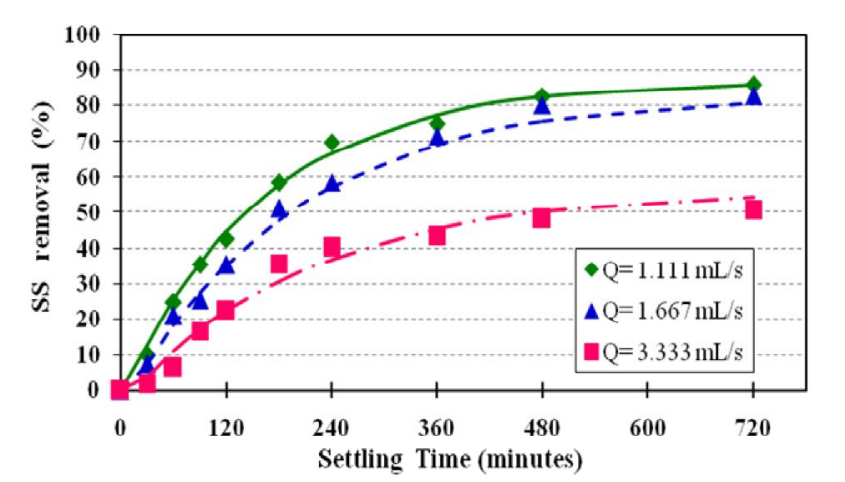

Fig. 5. Percentages removal of suspended solids by Electrocoagulation using single flow method at cell current of $0.8 \mathrm{~A}$. 
As seen from Figure 5, the optimum result of SS removal efficiencies by using treatment process without magnetic fields $(B=0.00 \mathrm{~T})$, for the flowrate of $1.1 \mathrm{~mL} / \mathrm{s}$ is reached more than $85 \%$ (exactly is $85.9 \%$ ). Whereas for the flowrate of $1.7 \mathrm{~mL} / \mathrm{s}$ and $3.3 \mathrm{~mL} / \mathrm{s}$ are reached more than $82 \%$ and $54 \%$, respectively. On the other hand,
Figure 6 illustrates of SS removal efficiencies by using combined process of EC and magnetic fields $(B=0.16 \mathrm{~T})$. In this combined process, besides of the influences of flowrate are also seen a significant influence of the magnetic fields.

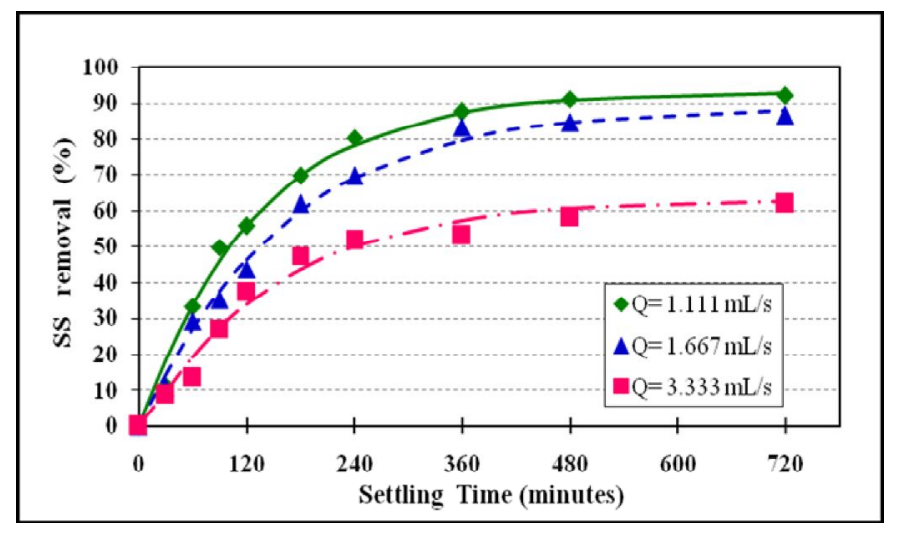

Fig. 6. Percentages removal of suspended solids by combined of EC and magnetic fields $(B=0.16 \mathrm{~T})$ using single flow method at cell current of $0.8 \mathrm{~A}$.

Shown in the curves of Figure 6, the faster of the flowrate will have unsatisfactory results. Conversely, if the flowrate are set close to the optimum time, then the results become more increased. Moreover, if compared with Figure 5 then the curves in Figure 6 also showed improved results due to the influence of magnetic fields. With this combined processing techniques, SS removal efficiencies are increased reached more than 92\%, 86\% and $62 \%$ at flowrate of $1.1 \mathrm{~mL} / \mathrm{s}, 1.7 \mathrm{~mL} / \mathrm{s}$ and $3.3 \mathrm{~mL} / \mathrm{s}$, respectively.

A clearer comparison of the influence of these magnetic fields can be seen on the curve in Figure 7. Wherein shown in Fig. 7, SS removal by electrocoagulation technique at flowrate of $1.1 \mathrm{~mL} / \mathrm{s}$ are obtain optimum results of $86 \%$, when combined with the technique of EC-magnetic fields $(B=0.16 \mathrm{~T})$ are obtain better results more than $92 \%$.

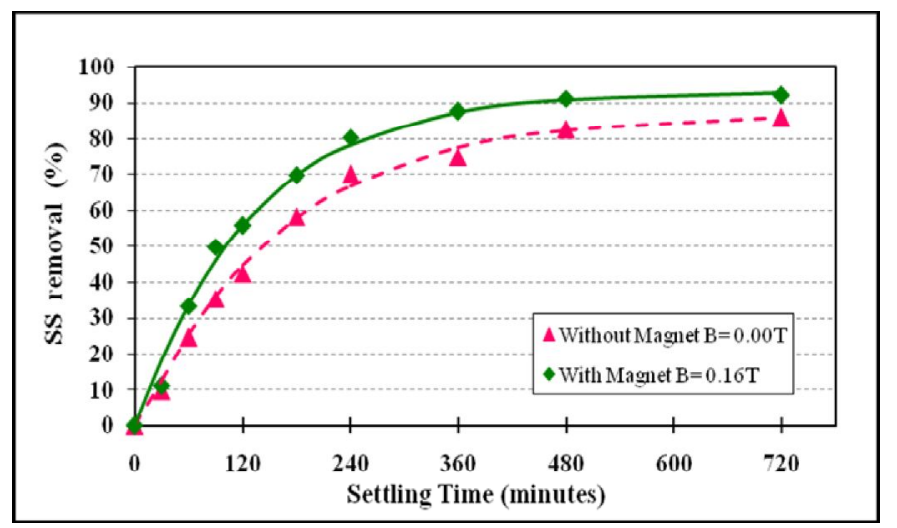

Fig. 7. Comparison of magnetic fields ability on SS removal percentage by using single flow method at $\mathrm{Q}=1.1 \mathrm{~mL} / \mathrm{s}$ and $\mathrm{i}=0.80 \mathrm{~A}$ 

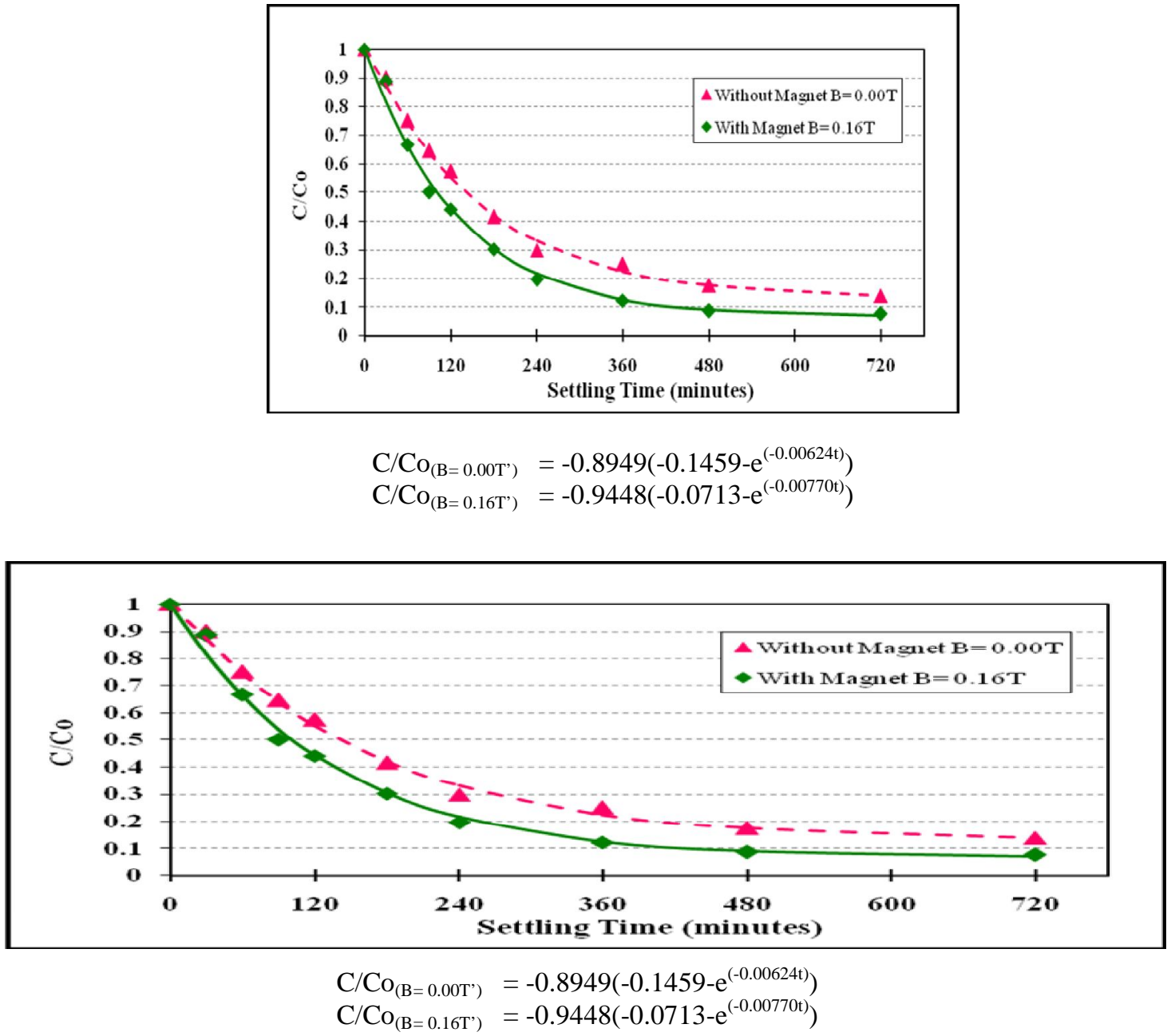

Fig. 8. Comparison of magnetic fields ability on rate of change of SS removal by using single flow method at $\mathrm{Q}=1.1 \mathrm{~mL} / \mathrm{s}$ and $\mathrm{i}=0.8 \mathrm{~A}$

On the other hand, if the results of these experiments were analyzed using the curve of rate of change (C / Co), then the result will be presented as shown in Figure 8. From this figure, the study results indicate that the removal of suspended solids by using EC technology combined magnetic fields, also in accordance with equation (3). As Shown in Figure 8 that the $k$ values will increase with applied of the combined technique, when compared with the electrocoagulation process alone. This means that the ability of the magnetic fields has a significant influence on the process of suspended solids removal from wastewater.

Furthermore, this study also analyzed using factorial design graph, which the output of this analysis are two graphs plot, i.e.: main effect plot and interaction plot, Based on factorial design graphs as shown in Figure 9 and Figure 10, it were clear that wastewater treatment by using combined of EC and magnetic fields gives better results than without magnetic fields. 


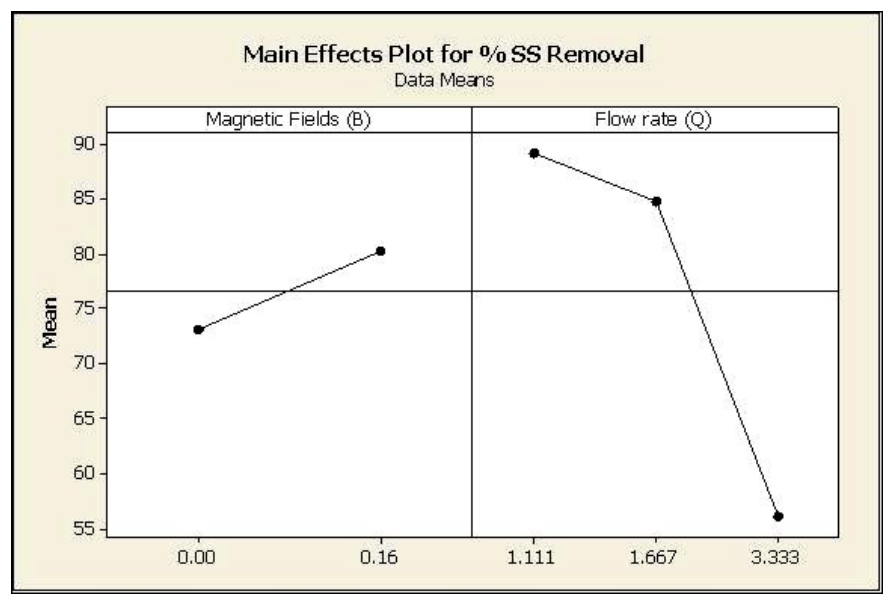

Fig. 9. Main Effect Plot for SS removal using Factorial Design graphs.

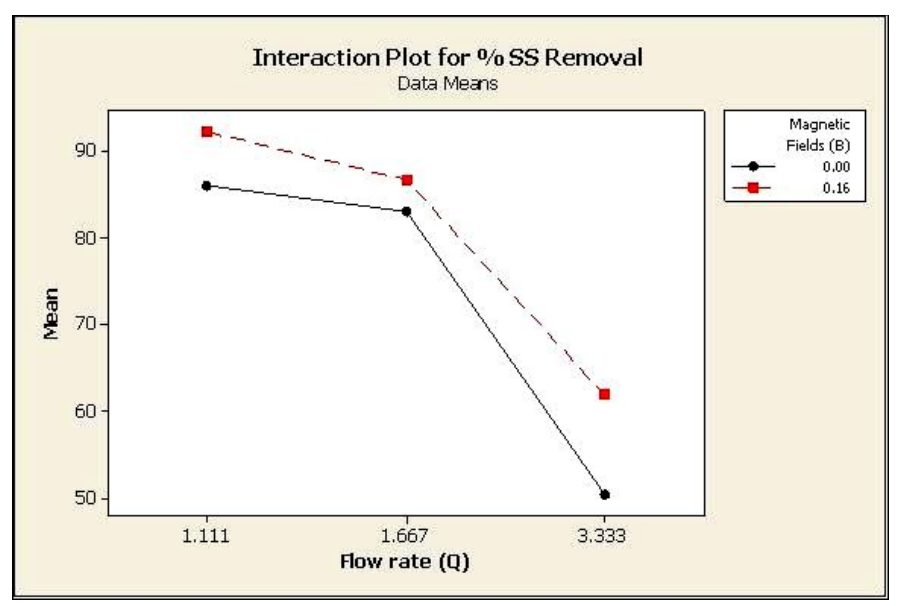

Fig. 10. Interaction Plot for SS removal using Factorial Design graphs.

As depicted in Figure 9, that the magnetic field and the flowrate have major influences on suspended solids removal. These two factors have the opposite effect. The stronger of magnetic field, it will give a greater effect on suspended solids removal. Conversely, the faster of flowrate, it will give a smaller effect on suspended solids removal. While in Figure 10, illustrates the interaction between flowrate and the two technologies are simulated for SS removal. It appears that both technologies have the same effect in each of flowrate, but the combined technology with magnetic fields are gives better results.

\section{Iron (Fe) Content in the Sludge}

Suspended solids that have been coagulating will be settling to the bottom, as shown in Figure 11. To determine the presence of Fe content and concentration, make do with the SEM (Scanning Electron Microscope) analysis on standard glass-fiber filter that have been used to filter for suspended solids (see in Fig. 11 and Fig. 12).
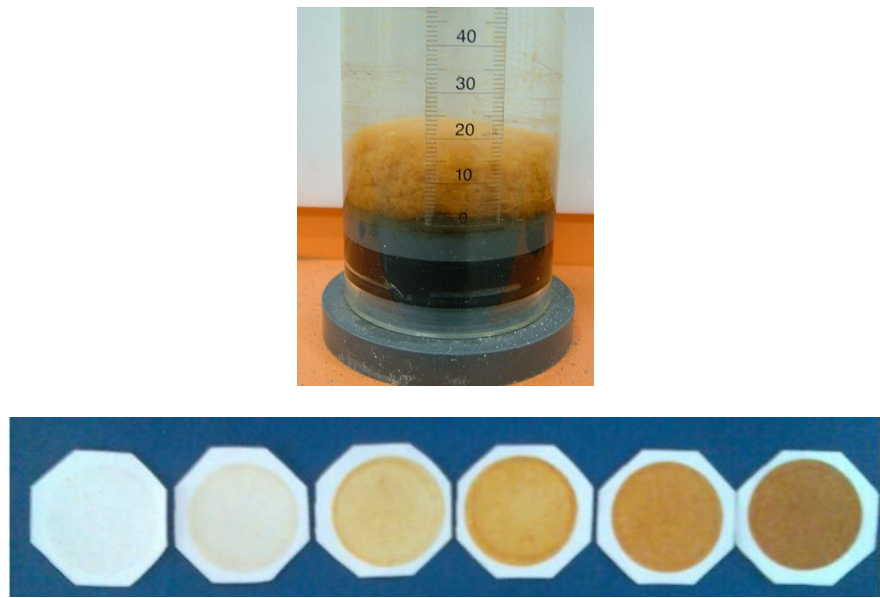

Fig. 11. Sludge of settled SS on the bottom of settling column and the glass-fiber filter that have been filtered the SS at 0 min (before treatment), $10 \mathrm{~min}, 15 \mathrm{~min}, 20 \mathrm{~min}, 25 \mathrm{~min}$ and $30 \mathrm{~min}$, respectively. 


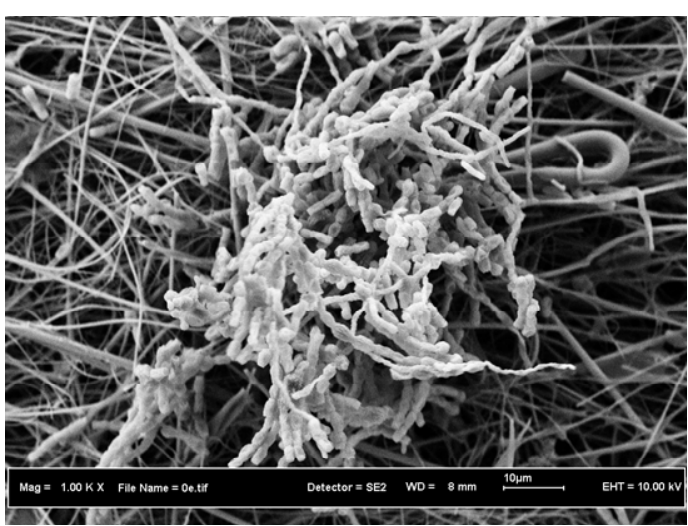

(a) before treatment process.

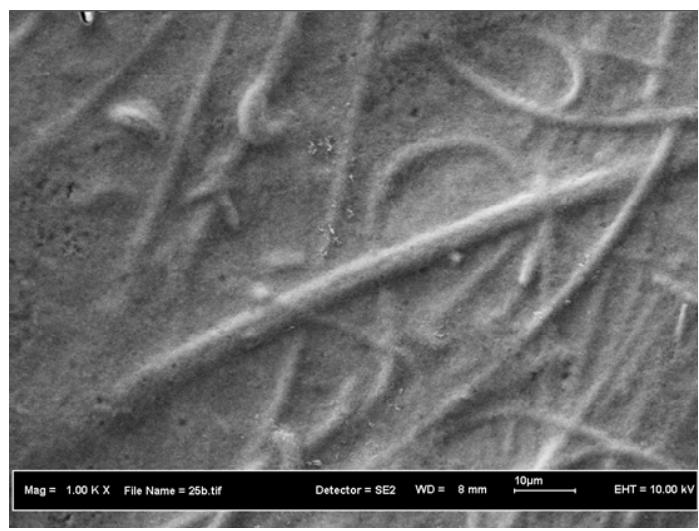

(c) at treatment time $=30 \mathrm{~min}$.

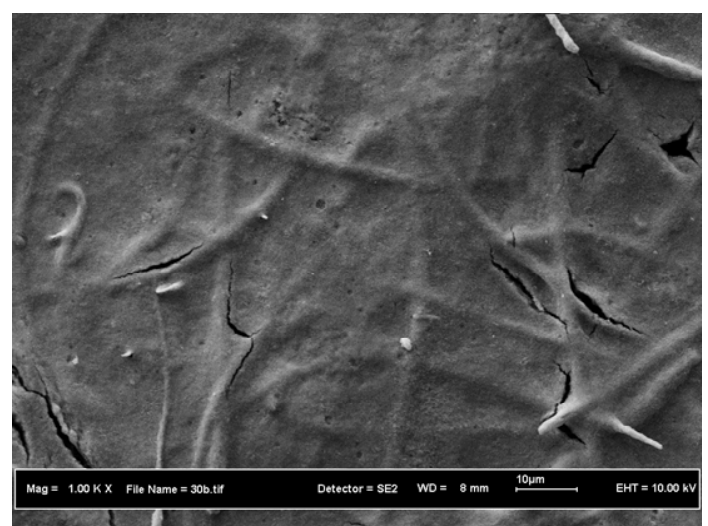

(b) at treatment time $=25 \mathrm{~min}$.

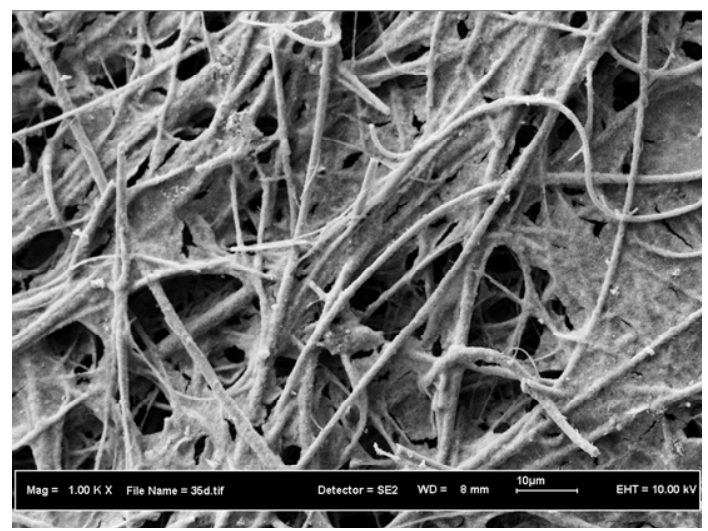

(d) at treatment time $=35 \mathrm{~min}$

Fig. 12. SEM images of coagulation process of suspended solids.

In the SEM image as shown in Figure 12 can explain more details about the optimum time. As shown in Figure 12(a) at the beginning before the wastewater treatment is seen that there is no coagulation of the suspended solids. Fig. 12(b) and Fig. 12(c) explained that coagulation process begins when the treatment processing has been going on for 15 minutes, and complete coagulation occurs between 25 to 30 minutes. In Figure 12(d) when the processing time more than 35 minutes there was an anti climax of coagulation process, where the coagulation has been experiencing breakdown again or rupture. Thus, based on Figure 12 can determined that the optimum time of the EC process is 30 minutes by using the current $(\mathrm{i})=0.80 \mathrm{~A}$ and the distance between electrode $(\mathrm{d})=14 \mathrm{~mm}$. This complements the results of the ANOVA statistical analysis shown in Figure 4. 


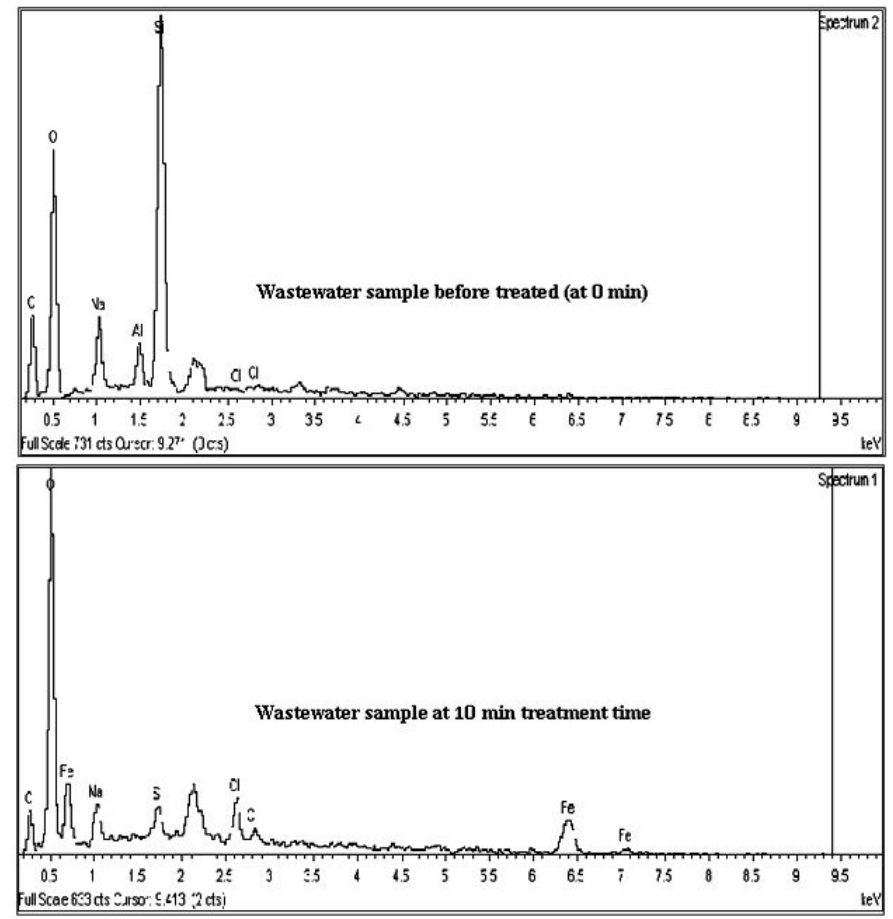

Fig. 13. The spectrum image of chemical elements quantity of suspended solids sample on wastewater before treated and at 30 min treatment time.

Table 5: Weight percentages of Fe contents in the sludge.

\begin{tabular}{||c|c|c||}
\hline \hline No. & $\begin{array}{c}\text { Treatment Time } \\
\text { (minutes) }\end{array}$ & $\begin{array}{c}\text { Weight Percentages } \\
(\%)\end{array}$ \\
\hline \hline 1 & 0 & 0 \\
\hline 2 & 25 & 38.34 \\
\hline 3 & 30 & 37.42 \\
\hline 4 & 35 & 29.25 \\
\hline
\end{tabular}

The results of SEM analysis can be used to determine the quantities of chemical elements, especially $\mathrm{Fe}$ contained in the suspended solids are filtered by glassfiber filters. The results of chemical analysis of Fe content in the SEM examination have been done, it is known that the Fe content in the filter samples before treatment was $0 \%$. Furthermore, the quantity of Fe content increased to $38.34 \%$ and $37.42 \%$ in the filter samples were treated for 25 minutes and 30 minutes, respectively. More detail can be seen in the spectrum image is shown in Figure 13.

From the data, the weight percentage of $\mathrm{Fe}$ at treatment time of 25,30 and 35 minutes are $38.34 \%$, $37.42 \%$ and $29.25 \%$, respectively. More specifically, the weight percentage of $\mathrm{Fe}$ in the sludge during the treatment time, can be seen in Table 5 and Figure 14.

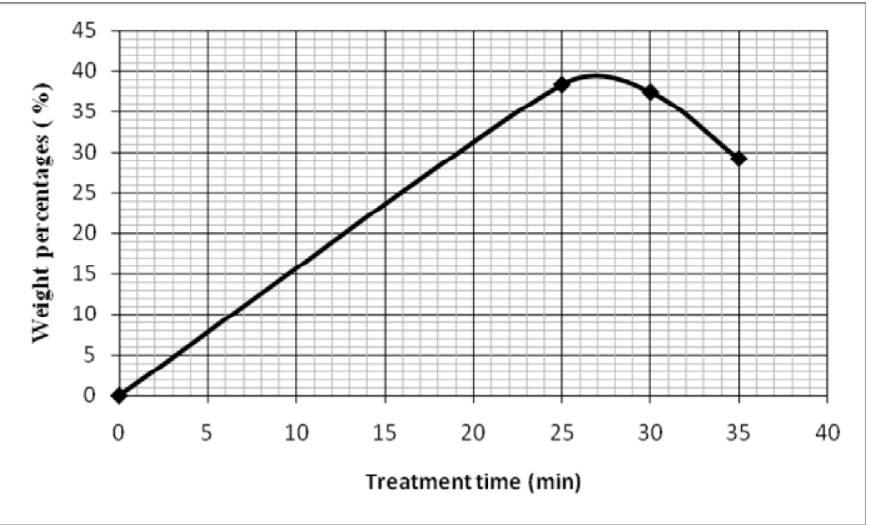

Fig. 14. Weight percentages of Fe contents in the sludge.

As shown in Figure 14, at the beginning before the wastewater treatment is seen that there is no coagulation of the suspended solids. The coagulation process begins when the treatment processing has been going on for 15 minutes, and complete coagulation occurs between 25 to 30 minutes. As explained by Kobya et al. (2009 and 2011), in this processes, $\mathrm{Fe}^{2+}$ (ferrous) ions are released. And when the processing time more than 35 minutes there was an anti climax of coagulation process, where $\mathrm{Fe}^{3+}$ (ferric) ions are released and the coagulation has been experiencing breakdown again or rupture. Ferrous $\left(\mathrm{Fe}^{2+}\right)$, in chemistry, indicates a divalent iron compound (+2 oxidation state), as opposed to ferric, which indicates a trivalent iron compound $(+3$ oxidation state).

\section{CONCLUSION}

From the experiment and statistical analysis using RSM and ANOVA obtained optimum values, are: optimum time is 30 minutes, optimum distance is $14 \mathrm{~mm}$ and optimum cell current is $0.8 \mathrm{~A}$. From the experimental results also found that after passing through the optimum time, coagulation will be break down again or experiencing rupture. And if this process is continued, wastewater will turn brownish green color because of the increasing $\mathrm{Fe}^{3+}$ ions are released.

As shown in experimental results and the statistically analysis using Factorial Design from MINITAB, that the magnetic field and the flowrate has a major influences on suspended solids removal. These two factors have the opposite effect. The stronger of magnetic field, it will give a greater effect on suspended solids removal. Conversely, the faster of flowrate, it will give a smaller effect on suspended solids removal.

\section{ACKNOWLEDGMENT}

The authors are grateful for the financial support IRPA Grant: VOT 74146, by the Malaysian Ministry of Science, Technology and Innovation (MOSTI). We also wish to thank the Universiti Teknologi Malaysia (UTM) and Universitas Islam Sultan Agung (UNISSULA) for financial and other support provided. 


\section{REFERENCES}

1. Antony, J., (2003). Design of experiments for engineers and scientists, $1^{\text {st }}$ Edition, Butterworth Heinemann, Oxford.

2. APHA, (2005). Standard methods for the examination of water \& wastewater, $21^{\text {st }}$ Edition The American Public Health Association.

3. Calvo, L.S., Leclerc, J.P., Tnguy, G., Cames, M.C., Paternotte, G., Valentin, G., Rostan, A. and Lapicque, F., (2003). An electrocoagulation unit for the purification of soluble oil wastes of high COD, Environmental Progress, 22: 1, 57-65.

4. Can, O.T., Kobya, M., Demirbas, E. and Bayramoglu, M., (2006). Treatment of the textile wastewater by combined electrocoagulation, Chemosphere, 62, 181-187.

5. Carmona, M., Khemis, M., Leclerc, J.P. and Lapicque, F., (2006). A simple model to predict the removal of oil suspensions from water using the electrocoagulation technique, Chemical Engineering Science, 61, 1237-1246.

6. Chen, G., (2004). Electrochemical technologies in wastewater treatment, Separation and Purification Technology, 38, 11-41.

7. Daneshvar, N., Sorkhabi, H.A. and Kasiri, M.B., (2004). Decolorization of dye solution containing acid red 14 by electrocoagulation with a comparative investigation of different electrode connections, Journal of Hazardous Materials, B112, 5562.

8. Daneshvar, N., Oladegaragoze, A. and Djafarzadeh, N., (2006). Decolorization of basic dye solutions by electrocoagulation: an investigation of the effect of operational parameters, Journal of Hazardous Materials, B129, 116-122.

9. Ghernaout, D., Ghernaout, B., Saiba, A., Boucherit, A. and Kellil, A., (2009). Removal of humic acids by continuous electromagnetic treatment followed by electrocoagulation in batch using aluminium electrodes, Desalination, 239, 295-308.

10. Hernandez, I.L., Diaz, C.B., Morales, G.R., Bilyeu, B. and Nunez, F.U., (2009). Influence of the anodic material on electrocoagulation performance, Chemical Engineering Journal, 148 (1), 97-105.

11. Hiemenz, P.C. and Rajagopalan, R., (1997). Principles of colloid and surface chemistry, $3^{\text {rd }}$ edition, Marcel Dekker Inc., New York.

12. Holt, P.K., Barton, G.W., Wark, M. and Mitchell, C.A., (2002). A quantitative comparison between chemical dosing and electrocoagulation, Colloids and Surfaces A: 211, 233-248.

13. Ihara, I., Kanamura, K., Shimada, E. and Watanabe, T., (2004). High gradient magnetic separation combined with electrocoagulation and electrochemical oxidation for treatment of landfill leachate, Applied Superconductivity, IEEE Transaction, 14: 2, 1558-1560.

14. Ilhan, F., Kurt, U., Apaydin, O. and Gonullu, M.T., (2008). Treatment of leachate by electrocoagulation using aluminum and iron electrodes. Journal of Hazardous Materials, 154, 381-389.

15. Kobya, M., Can, O.T. and Bayramoglu, M., (2003). Treatment of textile wastewaters by electrocoagulation using iron and aluminum electrodes, Journal of Hazardous Materials, B100, 163178.

16. Kobya, M., Bayramoglu, M. and Eyvaz, M., (2007). Technoeconomical evaluation of electrocoagulation for the textile wastewater using different electrode connections, Journal of Hazardous Materials, 148, 311-318.

17. Kobya, M., Demirbas, E. and Akyol, A., (2009). Electrochemical treatment and operating cost analysis of textile wastewater using sacrificial iron electrodes, Water Science and Technology, 60: 9, 2261-227.

18. Kobya, M., Demirbas, E., Bayramoglu, M., and Sensoy, M.T., (2011). Optimization of electrocoagulation process for the treatment of metal cutting wastewaters with response surface methodology, Water Air Soil Pollut, 215, 399-410.

19. Kumar, P.R., Chaudhar, S., Khilar, K. and Mahajan, C., (2004). Removal of arsenic from water by electrocoagulation, Chemosphere, 55, 1245-1252.

20. Larue, O., Vorobiev, E., Vu, C. and Durand, B., (2003). Electrocoagulation and coagulation by iron of latex particles in aqueous suspensions, Separation and Purification Technology, 31, 177-192.

21. Matteson, M. J., Dobson, R.L., Glenn Jr., R.W., Kukunoor, N.S., Waits III, W.H. and Clayfield, E.J., (1995). Electrocoagulation and separation of aqueous suspensions of ultrafine particles, Colloids and Surfaces A: 104, 101-109.

22. Meunier, N., Drogui, P., Montane, C., Hausler, R., Mercier, G. and Blais, J.F., (2006). Comparison between electrocoagulation and chemical precipitation for metals removal from acidic soil leachate, Journal of Hazardous Materials, B137, 581-590.

23. Mollah, M.Y.A., Schennach, R., Parga, J.R. and Cocke, D.L., (2001). Electrocoagulation (EC) - science and applications, Journal of Hazardous Materials, B84, 29-41.

24. Montgomery, D.C., (2001). Design and analysis of experiments, $5^{\text {th }}$ edition. John Wiley \& Sons, Inc., New York.

25. Ni'am, M.F., Othman, F., Sohaili, J. and Fauzia, Z., (2005). A combined magnetic field and electro-coagulation process for wastewater treatment, Proc. of Brunei Int'l. Conference on Engineering and technology (BICET). August 15-18, ITB Brunei Darussalam, 389-394.

26. Ni'am, M.F., Othman, F., Sohaili, J. and Fauzia, Z., (2006). Combined magnetic field and electrocoagulation process for suspended solid removal from wastewater, Proc. of the $1^{\text {st }}$ International Conference on Natural Resources Engineering \& Technology (INRET), July 24-25, Putrajaya, Malaysia, 384-393, 2006.

27. Ni'am, M. F., Othman, F., Sohaili, J. and Fauzia, Z., (2007a) Electrocoagulation technique in enhancing COD and suspended solids removal to improve wastewater quality, Water Science and Technology, 56: 7, 47-53.

28. Ni'am, M. F., Othman, F., Sohaili, J. and Fauzia, Z., (2007b). Removal of COD and turbidity to improve wastewater quality using electrocoagulation technique, The Malaysian Journal of Analytical Sciences, 11: 1, $198-205$.

29. Ni'am, M. F., Othman, F., Sohaili, J. and Fauzia, Z., (2008). Electrocoagulation technique for removal of COD and turbidity to iImprove wastewater quality, Ultrapure Water Journal, 25: 3, 3642.

30. Othman, F., Sohaili, J. and Zularisham, (2001). Application of magnetic field to enhance wastewater treatment process, The $8^{\text {th }}$ Joint MMM-Intermag Conference, January 7-11, San Antonio, Texas: IEEE.

31. Othman, F., Ni'am, M. F., Sohaili, J. and Fauzia, Z., (2005). Removal of suspended solid from wastewater by combined magnet and electrocoagulation, Proc. of MSA-International Science Congress (ISC), August 3 - 6, Malaysia.

32. Othman, F., Sohaili, J., Ni'am, M.F. and Fauzia, Z., (2006). Enhancing suspended solids removal from wastewater using Fe electrodes, Malaysian Journals of Civil Engineering, 18: 2, 139-148.

33. Shaw, D.J., (1970). Introduction to colloid and surface chemistry, $2^{\text {nd }}$ edition, Butterworth \& Co., London.

34. Sohaili, J., (2003). Effect of magnetic fields on the settling of suspended particles in sewage, University of Technology Malaysia, Ph.D Thesis.

35. Sohaili, J., Othman, F. and Zularisham, (2004). Effect of magnetic fields on suspended particles in sewage, Malaysian Journal of Science, 23, 141-148.

36. Tchamango, S., Njiki, C.P.N., Ngameni, E., Hadjiev, D. and Darchen, A., (2010). Treatment of dairy effluents by electrocoagulation using aluminium electrodes, Science of the Total Environment, 408, 947-952.

37. Tsouris, C., DePaoli, D.W., Shor, J.T., Hu, M.Z.C. and Ying, T.Y., (2001). Electrocoagulation for magnetic seeding of colloidal particles, Colloids and Surfaces A: 177, 223-233.

38. Zhu, B., Clifford, D.A. and Chellam, S., (2005). Comparison of electrocoagulation and chemical coagulation pretreatment for enhanced virus removal using microfiltration membranes, Water Research, 39, 3098-3108. 
39. Zongo, I., Maiga, A.H., Wethe, J., Valentin, G., Leclerc, J.P., Paternotte, G. and Lapicque, F., (2009). Electrocoagulation for the treatment of textile wastewater with $\mathrm{Al}$ or $\mathrm{Fe}$ electrodes: compared variations of COD levels, turbidity and absorbance, Journal of Hazardous Materials, 169, 70-76. 